\title{
The Effect of Religiosity on Knowledge-Mediated Stigmatization Against People with HIV-AIDS
}

\author{
Baidi Bukhori ${ }^{1}$, Ema Hidayanti ${ }^{2}$,Fuad Nashori ${ }^{3}$, Hamdan Said ${ }^{4}$, Arif Subiyanto ${ }^{5}$, \\ Firmanto Adi Nurcahyo ${ }^{6}$ \\ Universitas Islam Negeri Walisongo ${ }^{1,2}$, Universitas Islam Indonesia ${ }^{3}$ \\ \{baidi_bukhori@walisongo.ac.id ${ }^{1}$,ema.hidayanti@walisongo.ac.id², fuadnashori@yahoo.com ${ }^{3}$ \}
}

\begin{abstract}
This study is aimed to examine the direct influence of religiosity and knowledge of HIV/AIDS on the stigma faced by PLWHA. It also examines the indirect effect of religiosity on stigma towards PLWHA through knowledge of HIV/AIDS. The study subjects were 179 Muslim prisoners, selected using the cluster random sampling technique. Data were collected using a PLWHA stigma scale; a religious scale; a religious knowledge test; and an HIV/AIDS knowledge test. Mediation analysis was performed using the SPSS PROCESS macro, model four. The results show that the direct influence of religion on stigma towards PLWHA was not significant $(\beta=-0.465, \mathrm{p}>0.05)$; that there was a direct influence of knowledge about HIV/AIDS on stigma encountered by PLWHA $(\beta=-0.80, p<0.05)$; and that religiosity in the stigma faced by PLWHA was indirectly influenced by knowledge of HIV/AIDS $(\beta=-0.695)$. This shows the full role of knowledge mediation.
\end{abstract}

Keywords: Stigma; People Living with HIV/AIDS; Religiosity; Knowledge of HIV/AIDS; Pprisoners

\section{Introduction}

Since the time the Human Immunodeficiency Virus (HIV) and Acquired Immune Deficiency Syndrome (AIDS) were first discovered, there have been various responses from society to people living with HIV/AIDS (PLWHA), one of which is stigma [1], [2]. Kipp et al. state that stigma is a social process or personal experience characterized by exclusion, rejection, reproach, or devaluation due to adverse social assumptions about the individual or group regarding certain health problems [3]. It is a form of prejudice that discredits or rejects a person or group because they are considered to be different from the majority [2].

Stigma causes PLWHA to be humiliated and prevented from associating with the surrounding environment and society [4], worsening cases of depression and other mental health disorders [1], and leading to low psychological well-being [5], and suicidal tendencies [6]. It can even weaken the immune system if not tackled appropriately [7]. Another effect of stigma is that patients are reluctant to seek information about how to protect themselves against HIV/AIDS, thus hampering the process of disease prevention, testing and treatment [8]. This has accelerated the spread of the HIV/AIDS epidemic [9]. 
The emergence of stigma against PLWHA is caused by several factors, including religiosity and knowledge of HIV/AIDS. In this study, religiosity is an independent variable, and knowledge of HIV/AIDS is a mediating variable, because they are two different, but related, issues. Religion teaches its adherents to seek any knowledge [10]. Khraim asserts that religious followers understand that religion encourages them to seek useful knowledge. In Islam, such knowledge has a broad meaning, referring not only to religious knowledge but also to general knowledge, including that of HIV/AIDS [11].

Religion can be interpreted as the level of individual involvement in it. Referring to the views of Ancok, Suroso and Ardani, religiosity is a person's level of knowledge, belief, implementation, and appreciation of the religious teachings in which he or she believes [12]. In line with the above view, according to Gufron and Suminta religiosity can be interpreted as the internalization of religion within a person [13]. Religion can also be interpreted as a condition that exists in individuals that can encourage them to think and behave in accordance with the teachings of the particular religion [14].

Stark and Glock dissects religiosity into five dimensions: 1) Ideological dimension (faith), which refers to the extent to which individuals believe in the virtues and truth of religious tenets, especially the most fundamental and dogmatic teachings; 2). Ritualistic or practical dimension, which refers to individuals' ritual observance; 3). Experiential dimension, which refers to the profundity of individuals' religious experience; 4). Intellectual dimension, which refers to the depth of individuals knowledge and understanding of their religious teachings as dictated by the holy scriptures; 5). Practical or consequential dimension, which refers to individuals' behavior or personal traits that are religiously motivated [15]. Ancok et al. confirm that the above dimensions can be used to explain Muslims' religiosity [12].

Hawari argues that religion provides the faithful with guidance in addressing problems in their lives [16]. In line with that, Tiaranita, Saraswati and Nashori contend that individuals' religiosity unwavering faith in their religion - helps explain their behaviour and attitude, and ignominious stigma on people with HIV/AIDS exemplifies the dark aspect of religiosity [17]. One should keep in mind that religions not only admonish against prejudicing and stigmatizing HIV/AIDS patients, but also teach the followers to show and practice compassion to their fellow humans [18], including those who suffer fromHIV/AIDS[19]. Meta-analytic studies by Bukhori has demonstrated negative correlation between intrinsic religious orientation and prejudice [20]. Another study by Nashori and Nurjannah further supports the view that religious sensibility is negatively correlated to social prejudice [21]. Another factor that potentially causes stigma against patients of HIV/AIDS is knowledge about the syndrome [22], [23]. Their research findings agree with Ahwan who asserts that people's knowledge about HIV/AIDS is still limited and their erroneous views aboutHIV/AIDS often times cause them to stigmatize and discriminate against HIV/AIDS patients because they do not have sufficient knowledge about the methods of HIV transmission, symptoms and preventions of HIV/AIDS [19] [24].

Based on the above narration we can theorize that knowledge about HIV/AIDS significantly affects people's stigma against HIV/AIDS patients. Knowledge of HIV/AIDS serves as a mediating variable of the correlation between religiosity and stigma against people with HIV/AIDS. This study is radically different from the previous research that isolated the independent variables and not incorporated them simultaneously in the analysis. What is more, the previous studies used single linear design which assumed that all factors are directly correlated to stigma against HIV/AIDS patients and thus ignored the possibility of indirect relationship (through the other mediating variables). What sets this study apart is the fact that the existing studies on stigmatization against people with HIV/AIDS took place in the western world; their generalizability is questionable, since we believe that a different research needs to be carried within the Indonesian setting due to the stark cultural differences between Indonesia 
and the western world. This fact justifies a different study on Indonesian people's stigmatization on HIV/AIDS patients, especially within prisons. This study was designed to make up for the deficiencies of the previous studies in hope that the outcomes could be used to help remove the stigma attached to people who live with HIV/AIDS. In addition to examining the effect and direct correlation between variables, this research also sought to examine the knowledge-mediated direct or indirect effect of religiosity on stigma against HIV/AIDS patients.

This study examined stigma against people living with HIV/AIDS using two variables: respondents' religiosity and knowledge about HIV/AIDS. Religiosity was chosen as the independent variable because of the fact that Indonesian people are highly pious and strongly adhere to the existing religious traditions [19]. What is more, religion strongly influences the way people behave and perceive things [25]. Additionally, people's knowledge about HIV/AIDS is still very limited [9]. Lack of knowledge or ignorance has led people to discriminate against those who suffer from HIV/AIDS [19].

Among interesting subjects that deserve scholastic study is the population of prison inmates serving their time in Indonesian penitentiaries. Prisons are considered to be hot spots of HIV/AIDS transmission for several reasons: inmates share needles for making tattoos and body piercings, they share razors for shaving [26]. One prison located in the province of Central Java has inmates who tested positive for HIV/AIDS, and their presence has sparked stigma and discrimination, and this reflects the same phenomenon in the wider society [1].

Based on the above background, the authors resolved to carry out a study on stigma against prison inmates living with HIV/AIDS, in the hope that the findings would make practical contribution in the form of accurate information about the direct effect of religiosity on stigma against people with HIV/AIDS and indirect effect of knowledge about the syndrome on the stigma, which would help us create preventive measures and efforts at reducing the stigma. Reducing stigma against prison inmates with HIV/AIDS will result in improved condition: they will receive more humane treatment and their rights are reserved. Reduced stigma against HIV/AIDS patients in the prison will also result in prompt or speedy actions and treatment that in turn will curb or contain HIV/AIDS transmission and discourage behaviour that spread the disease.

Research hypotheses: (1). Religiosity and knowledge about HIV/AIDS affect people's stigma against HIV/AIDS patients. (2). Religiosity directly and indirectly affects (mediated by knowledge about HIV/AIDS) stigma against people suffering from HIV/AIDS.

\section{Method}

\subsection{Research Participants}

Subjects of this research are Muslim inmates of a prison located in Central Java, Indonesia. Muslim inmates are selected for the following considerations: 1). The majority of inmates in the locus of the research are Muslims (93,9\%). 2). Research instrument for this study were designed specifically for Muslim participants. The total number of participants is 526 in a penitentiary located in Central Java, Indonesia. Cluster random sampling was the technique used for this research, and out of 526 inmates, 179 were used for testing.

\subsection{Measurement}


For data collection the authors used two scales, namely: stigmatization against patients of HIV/AIDS and religiosity. Scale of stigmatization was based on Kipp et al. model showing that stigma takes three forms: alienation, rejection and condemnation [3]. For scale of religiosity the authors refer Stark and Glock, and Ancok et al. who dissected religiosity into five dimensions: ideology/faith dimension, ritualistic/practical dimension, experiential, intelectual/knowledge and consequential dimensions [12], [15]. The two scales above were developed using Likert's model (we used positive / negative statements followed by four response options, namely: highly agree, agree, disagree, and highly disagree, depending on the subjects' opinions or views). Respondents' scoring of scale items reflects their opinion about the most favorable or least favorable items, on the scale of 1 to 4 or 4 to 1 .

Table 1. presents test and scale's reliability Reliability Coefficient

\begin{tabular}{clc}
\hline No & \multicolumn{1}{c}{ Variable } & Cronbach's Alfa \\
\hline 1 & Stigma against people living with HIV/AIDS & 0,922 \\
2 & Religiosity & 0,948 \\
3 & Test on religiosity & 0,862 \\
4 & Test on knowledge about HIV/AIDS & 0,943 \\
\hline
\end{tabular}

\subsection{Statistical Analysis}

Mediation analysis was performed using SPSS version 24 to find out if knowledge mediates the effect of religiosity on stigma against people with HIV/AIDS. For this purpose, the authors used PROCESS version 3.4 model 4. The analysis displayed some paths (See Figure 1).Path a tested the regressive coefficient of the effect of religiosity on knowledge while path $\mathrm{b}$ tested the effect of knowledge on stigma. Path ab representsindirect effect, while path jalur c' represents thedirect effect. Path c tested the total effect of religiosity on stigma. To test the presence of mediating effect we used PROCESS that yieldedbootstrappedhaving the confidence interval of $95 \%$. Significant mediation is evident through the range of confidence interval indirect effectthat excluded zero (0) [27].

A

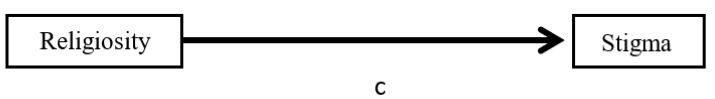

B

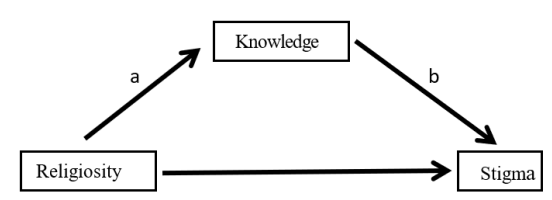

Fig 1. (A) Direct effect of religiosity on stigma. (B) The effect of knowledge-mediated religiosity on stigma.

\section{Findings and Discussions}

Figure 2. presents the result of research analysis. Direct effect of religiosity on stigma against HIV/AIDS patients (not mediated by knowledge of HIV/AIDS) showed significant result $(\beta=-1.16$, 
$\mathrm{p}<0.05$ ), and this condition is the prerequisite for the next stage of mediation analysis. Analysis shows the effect of religiosity on knowledge about HIV/AIDS $(\beta=0,80, p<0.05)$. Additionally, measurement shows the significant effect of knowledge about HIV/AIDS on stigma against patients of HIV/AIDS $(\beta=-0,86, p<0.05)$. It was found that knowledge about HIV/AIDS negatively affects stigma against patients of HIV/AIDS.

Testing onindirect effect ( $\mathrm{ab}$ path) gave the value of $-0,695$, while testing on thedirect effect (path c') gave the value of $-0,465$ ( $p>0.05$ ), thus resulting in the total effect (path c) of $-1.1654(\mathrm{p}<0.05) .95 \%$ confidence interval of the indirect effect ranges between -1.2124 and -0.1408 . Since this range is below zero, we could infer there is indirect effect of religiosity on stigma, which is to say that knowledge about HIV/AIDS significantly mediates the effect of religiosity on stigma.

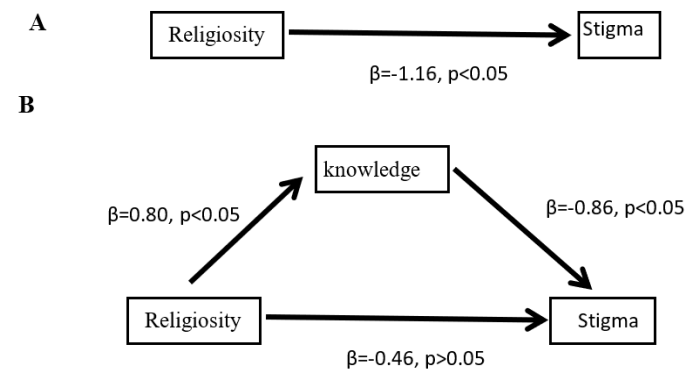

Fig 2. Presents the (A) direct effect of religiosity on stigma and (B) knowledge-mediated effect of religiosity on stigma.

\section{Discussion}

The outcomes of the study show that higher level of religiosity will result in lower stigmatization against patients of HIV/AIDS, because religion discourage all forms of prejudice and stigmatization. Stigma can manifest itself in the tendency to discredit or reject other people simply because they are different [28]. Religion admonishes against bad presumptions without convincing proofs [29]. Highly religious individuals are fully aware of religious teachings and restrictions and they will exercise the highest level of prudence in everything that they do. The holy scripture outlaws all forms of prejudice (Q.S. al-Hujarat: 12). Levelling groundless accusations at other people will lead to a lot of damage [30]. This principle is well understood by all Muslims therefore they will be extremely careful as not to let prejudice control their actions: stigmatizing people with HIV/AIDS is discouraged as this constitutes a capital sin. Within the context of life in the prison, stigmatizing the fellow prisoners who live with HIV/AIDS is deemed inappropriate, so the tendency for the occurrence of this case can be minimized.

Data analysis further demonstrates that religiosity positively affects knowledge about HIV/AIDS. Higher religiosity goes hand in hand with higher exposure to knowledge about HIV/AIDS, and the vice versa. Close correlation between religiosity and knowledge about HIV/AIDS finds its support in Khraim's position that prime among the dimensions of Islamic religiosity is individuals' strong fervor in seeking religious education [11]. This dimension is related to various kinds of education (knowledge) that make positive contributions to religiosity (that manifests in Muslims' habit of going to mosques to attend religious sermons, watching religious programs on television or reading religious books. It goes without saying that seeking knowledge about HIV/AIDS is closely linked to one dimension of Islamic religiosity: Islamic ethical principles and universality which shows the demarcation line between what is 
good and what is bad [31]. Religious sermons on the social media and books about HIV/AIDS present many discussions of how Islam view the phenomenon [16]

Data analysis further shows that knowledge about HIV/AIDS strongly affects stigmatization against people living with this syndrome. Deeper knowledge about the syndrome leads to lower stigma. Conversely, less knowledge about the syndrome will lead to higher stigmatization against people living with HIV/AIDS. This lends credibility to the research by Waluyo, Culbert, Levy and Norr, all of which show the significant effect of knowledge about HIV/AIDS on the stigma against the patients of this syndrome [22]. Keeping in mind that religiosity and knowledge have significant contribution to stigma against HIV/AIDS patients, this research aimed at finding out the role or influence of these variables in the case of stigmatization against patients of HIV/AIDS. It was hypothesized that knowledge mediates the effect of religiosity on stigma. To put it another way: knowledge is a mediating factor.

'Full mediation' and 'partial mediation' are frequently used to describe the role of mediator. Researchers report the presence of full mediation of mediator in the case of X's effect on $\mathrm{Y}$ if, upon finding significant indirect effect, they cannot find the effect of $\mathrm{X}$ on $\mathrm{Y}$. Conversely, if they still find the effect of $\mathrm{X}$ on $\mathrm{Y}$ when the mediator is fully under control, they will report that the mediator partially mediated X's effect on Y [32]. Research findings indicate that religiosity's effect on stigma against patients of HIV/AIDS becomes less significant when the variable of knowledge is introduced into the analysis. This shows that knowledge fully mediates the effect of religiosity on stigma, and this is easily understood since religiosity is the factor that motivates prison inmates to apply what they know into their daily lives: they will stop attaching stigma to people living with HIV/AIDS.

The absence of effect of religiosity on stigma against people living with HIV/AIDS shows that direct effect of stigma against people living with HIV/AIDS is insignificant. This finding pinpoints the fact that religiosity is actually unrelated to stigma against HIV/AIDS patients, the perceived role of religiosity on the stigma is caused by people's knowledge about the syndrome. So it can be inferred that knowledge about HIV/AIDS is the mediator that gives the way to religiosity to affect stigmatization (See Fig. 2).

\section{Conclusion}

Religiosity has its direct effect on stigma against HIV/AIDS patients. The more religious individuals will show lower stigmatization against people who suffer from HIV/AIDS. The less religious people will exhibit stronger stigma, and the indirect effect of it stronger stigma against HIV/IDS patients.

Mediation analysis shows less significant direct effect of religiosity on stigma against HIV/AIDS patients, direct effect of knowledge of HIV/AIDS on stigma against HIV.AIDS patients, and the knowledge-mediated direct effect of religiosity on stigma against people living with HIV/AIDS, all of which pinpoint and highlight the full mediation of knowledge about the syndrome.

\section{References}

[1] A. M. Domlyn, Y. Jiang, S. Harrison, S. Qiao, and X. Li, "Stigma and psychosocial wellbeing among children affected by parental HIV in China," AIDS Care, pp. 1-8, 2019.

[2] L. F. Heggeness, C. P. Brandt, D. J. Paulus, C. Lemaire, and M. J. Zvolensky, "Stigma and disease disclosure among HIV+ individuals: the moderating role of emotion 
dysregulation," AIDS Care, vol. 29, no. 2, pp. 168-176, 2016.

[3] A. M. Kipp et al., "Socio-demographic and AIDS-related factors associated with tuberculosis stigma in southern Thailand: a quantitative, cross-sectional study of stigma among patients with TB and healthy community members," BMC Public Health, vol. 11, no. 1, p. 675, 2011.

[4] C. Campbell, Y. Nair, S. Maimane, and Z. Sibiya, Understanding and challenging HIV/AIDS stigma. Durban: HIVAN, 2005.

[5] L. Li, S.-J. Lee, P. Thammawijaya, C. Jiraphongsa, and M. J. Rotheram-Borus, "Stigma, social support, and depression among people living with HIV in Thailand," AIDS Care, vol. 21, no. 8, pp. 1007-1013, 2009.

[6] O. Ferlatte, T. Salway, J. L. Oliffe, and T. Trussler, "Stigma and suicide among gay and bisexual men living with HIV," AIDS Care, vol. 29, no. 11, pp. 1346-1350, 2017.

[7] M. A. U. Sofro and E. Hidayanti, "A social support for housewives with HIV/AIDS through a peer support group," Psikohumaniora: Jurnal Penelitian Psikologi, vol. 4, no. 1, pp. 77-94, 2019.

[8] N. Varas-Díaz et al., "Beyond negative attitudes: examining HIV/AIDS stigma behaviors in clinical encounters," AIDS Care, vol. 29, no. 11, pp. 1437-1441, 2017.

[9] Z. Shaluhiyah, S. B. Musthofa, and B. Widjanarko, "Stigma masyarakat terhadap orang dengan HIV/AIDS," Kesmas Natl. Public Heal. J., vol. 9, no. 4, pp. 333-339, 2015.

[10] A. Rahman, Ensiklopediana ilmu dalam Al-Quran: rujukan terlengkap isyarat-isyarat ilmiah. Bandung: Mizan Pustaka, 2007.

[11] H. Khraim, "Measuring religiosity in consumer research from Islamic perspective," Int. J. Mark. Stud., vol. 2, no. 2, p. 166, 2010.

[12] D. Ancok, F. N. Suroso, and M. S. Ardani, Psikologi Islami: solusi Islam atas problemproblem psikologi. Yogyakarta: Pustaka Pelajar, 2018.

[13] M. N. Ghufron and R. R. Suminta, "Komitmen beragama dan kepuasan perkawinan pada pasangan yang bekerja menjadi tenaga kerja Indonesia," Psikohumaniora: Jurnal Penelitian Psikologi, vol. 2, no. 2, pp. 143-157, 2018.

[14] B. Bukhori, "Kesehatan mental mahasiswa ditinjau dari religiusitas dan kebermaknaan hidup," Psikologika J. Pemikir. dan Penelit. Psikol., vol. 11, no. 22, pp. 93-106, 2006.

[15] R. Stark and C. Y. Glock, American piety: The nature of religious commitment, vol. 1. California: University of California Press, 1968.

[16] D. Hawari, Konsep Islam memerangi AIDS" dalam Al-Qur'an. Yogyakarta: Dhana Bakti Primayasa, 2000.

[17] Y. Tiaranita, S. D. Saraswati, and F. Nashori, "Religiositas, kecerdasaan emosi, dan tawadhu pada mahasiswa pascasarjana," Psikohumaniora: Jurnal Penelitian Psikologi, vol. 2, no. 2, pp. 182-193, 2018.

[18] M. I. Taufiq, Panduan lengkap dan praktis psikologi Islam. Jakarta: Gema Insani, 2006.

[19] Z. Ahwan, "Stigma dan diskriminasi HIV \& AIDS pada orang dengan HIV dan AIDS (ODHA) di masyarakat basis anggota Nahdatul Ulama (NU) Bangil studi kajian peran faith based organization (FBO) dalam isu HIV," J. Kebangs. J. Ilm. Progr. Stud. Adm. Negara Univ. Yudharta Pasuruhan, vol. 6, no. 1, pp. 1-15, 2012.

[20] B. Bukhori, "Meta-analisis hubungan orientasi religius dengan prasangka rasial," AtTaqaddum, vol. 3, no. 1, pp. 105-123, 2011.

[21] F. Nashori and N. Nurjannah, "Prasangka sosial terhadap umat kristiani pada muslim minoritas yang tinggal di Indonesia Timur," J. Ilm. Psikol. Terap., vol. 3, no. 2, pp. 383-400, 2015. 
[22] A. Waluyo, G. J. Culbert, J. Levy, and K. F. Norr, "Understanding HIV-related stigma among Indonesian nurses," J. Assoc. Nurses AIDS Care, vol. 26, no. 1, pp. 69-80, 2014.

[23] H. Yang, X. Li, B. Stanton, X. Fang, D. Lin, and S. Naar-King, "HIV-related knowledge, stigma, and willingness to disclose: A mediation analysis," AIDS Care, vol. 18, no. 7, pp. 717-724, 2006.

[24] P. Dewi, "Pengetahuan siswa SMU Negeri 39 Cijantung, Jakarta Timur tentang HIV/AIDS tahun 2008 (Skripsi Tidak Dipublikasikan)," Fakultas Kesehatan Masyarakat, Universitas Indonesia, Jakarta, 2008.

[25] S. Notoatmodjo, Ilmu perilaku kesehatan. Rineka Cipta, 2010.

[26] N. A. Nuzzilah and D. M. Sukendra, "Analisis pengetahuan dan sikap marapidana kasus narkoba terhadap perilaku berisiko penularan HIV/AIDS,” J. Heal. Educ., vol. 2, no. 1, pp. 11-19, 2017.

[27] K. J. Preacher and A. F. Hayes, "Asymptotic and resampling strategies for assessing and comparing indirect effects in multiple mediator models," Behav. Res. Methods, vol. 40, no. 3, pp. 879-891, 2008.

[28] K. Greene and S. C. Banerjee, "Disease-related stigma: comparing predictors of AIDS and cancer stigma," J. Homosex., vol. 50, no. 4, pp. 185-209, 2006.

[29] A. A. Musthafa, Misteri lisan: karena lisan dapat menjerumuskan ke neraka atau memasukan ke surga. Jakarta: Mirqat, 2007.

[30] F. Nashori, Psikologi prasangka dan agresi. Yogyakarta: Universitas Islam Indonesia, 2017.

[31] A. I. Padela and H. Zaganjor, "Relationships between Islamic religiosity and attitude toward deceased organ donation among American Muslims: a pilot study," Transplantation, vol. 97, no. 12, pp. 1292-1299, 2014.

[32] D. D. Rucker, K. J. Preacher, Z. L. Tormala, and R. E. Petty, "Mediation analysis in social psychology: Current practices and new recommendations," Soc. Personal. Psychol. Compass, vol. 5, no. 6, pp. 359-371, 2011. 